IRSH 54 (2009), pp. 35 I-358 doi:I0.1017/So020859009990290

(C) 2009 Internationaal Instituut voor Sociale Geschiedenis

\title{
Introduction: Labour Institutions in a Global Perspective, from the Seventeenth to the Twentieth Century
}

\author{
A LESSANDRO STANZIANI \\ EHESS, Paris \\ CNRS (IDHE), Paris
}

E-mail: alessandro.stanziani@idhe.ens-cachan.fr

Summary: Comparative analyses of labour often assume a dividing line between free and forced labour which is universally applicable. The contributions to this special theme argue that the tensions between "freedom" and "unfreedom" may be identified more precisely as those between multiple notions and practices of contract, status, and social conditions. Free and unfree labour on the one hand, status and contract on the other, are historically determined categories. This introduction argues that those histories do not run in parallel but are strictly intersected. From that point of view, social and economic inequalities are mutually linked to legal entitlements; a modification in legal entitlements strongly influences the economic and social equilibrium, and vice versa. Underlying this conclusion is a perspective that is resolutely non-Eurocentric and global. We do not endeavour to find the "missing" freedom of contract in the "periphery", nor do we consider the "cultural" and economic domination of "the West" as a starting point. We stress instead the mutual connection between "peripheries" and "core" categories and practices. Such a bilateral circulation of ideas and practices contrasts with the argument according to which "the West" invented "freedom" and coercion as well.

Comparative analyses of labour often assume a dividing line between free and forced labour which is universally applicable. However, during the past twenty years, several researchers have stressed the divergent historical meanings and definitions of both "free" and "unfree" labour. In fact,

I. Bibliographical references can be found in Rebecca Scott, Thomas Holt, Frederick Cooper, and Aims McGuinness, Societies after Slavery: A Select Annotated Bibliography of Printed Sources on Cuba, Brazil, British Colonial Africa, South Africa and the British West Indies (Pittsburgh, PA, 2004); Rebecca Scott, "Defining the Boundaries of Freedom in the World of Cane: Cuba, Brazil, and Louisiana after Emancipation”, American Historical Review, 99 (1994), pp. 70-102; Joseph Calder Miller, Slavery and Slaving in World History: A Bibliography, 1900-1996 (Armonk, NY, 1999); and Seymour Drescher and Stanley Engerman (eds), A Historical Guide to World Slavery (New York [etc.], I998). 
until the middle, if not the end, of the nineteenth century, the notion of "free" labour was not that to which we are now accustomed; ${ }^{2}$ it included indenture, debt bondage, and several other forms of unfree labour; ${ }^{3}$ conversely, the official abolition of slavery saw not the disappearance of forced labour but rather the emergence of new forms. ${ }^{4}$ In both cases, coerced labour was in legal terms "free labour".

In this increasingly complex picture, the historical transition from "slavery" to "emancipation" has also been reassessed. For example, in French as well as in British and Spanish colonies, personal emancipation often took a long time, with years sometimes elapsing between the deed signed by the owner and the tax paid by the quasi ex-slave. During those years, the ex-slaves had an intermediate status between that of a slave and a freedman. ${ }^{5}$ That transitory period occurred too at a macrosocial and institutional level: general emancipation in the British colonies was accomplished after an intermediate period of apprenticeship lasting almost ten years (the $1830 s){ }^{6}$

The tensions between "freedom" and "unfreedom" may therefore be identified more precisely as those between multiple notions and practices of contract, status, and social conditions. The legal status of the indentured, coolies, and apprentices was historically different from that of their "masters", and this gave a peculiar value to the contracts in which they were involved. Nowadays, child labour confirms this link between the unequal legal status of socioeconomic actors and forms of contract. ${ }^{7}$

2. Tom Brass and Marcel van der Linden (eds), Free and Unfree Labour: The Debate Continues (Berne, 1997).

3. The amount of recent work on these subjects is immense, so I will give only a few examples. For servants and indenture see Robert Steinfeld, The Invention of Free Labor: The Employment Relation in English and American Law and Culture, 1350-I870 (Chapel Hill, NC, I991); Michael L. Bush, Servitude in Modern Times (Cambridge, 2000); David Galenson, White Servitude in Colonial America: An Economic Analysis (Cambridge, I98 I); and David Northrup, Indentured Labor in the Age of Imperialism, I834-I922 (Cambridge, I995).

4. P.C. Emmer (ed.), Colonialism and Migration: Indentured Labour Before and After Slavery (Dordrecht, I986); S. Engerman (ed.), Terms of Labor: Slavery, Serfdom and Free Labor (Stanford, CA, I999); and F. Cooper, T. Holt, and R. Scott, Beyond Slavery: Explorations of Race, Labor and Citizenship in Postemancipation Societies (Chapel Hill, NC, 2000).

5. On France see F. Régent, La France et ses esclaves (Paris, 2007). On Portugal and Brazil, see Espada Lima in the present volume (pp. 39I-4I6).

6. Seymour Drescher, Capitalism and Antislavery: British Mobilization in Comparative Perspective (New York, 1987).

7. UNICEF, The State of the World's Children (Oxford, I99I); ILO, International Labour Conference, Papers and Proceedings, 89th Session (Geneva, 200I), IPEC, Every Child Counts: New Global Estimates on Child Labour (Geneva, 2002); H. Cunningham and P. Viazzo, Child Labour in Historical Perspective, I800-1985: Historical Studies from Europe, Japan, and Colombia (Florence, I996); ILO, La fin du travail des enfants: un objectif à notre porté (Geneva, 2006); and Suzanne Miers, "Contemporary Forms of Slavery", Canadian Journal of African Studies [special issue on Slavery and Islam in African History: A Tribute to Martin Klein], 34 (2000), pp. 714-747. 
From that perspective, freedom of person and liberty of contract are no longer synonymous.

The papers collected here aim to push those analyses further and to show that, historically, the tensions between freedom and unfreedom were intimately linked to those between status and contract. The dividing line between freedom and unfreedom is fluid precisely because that between status and contract is too. Indeed, this long-standing opposition has been widely diffused in history and the social sciences since the last quarter of the nineteenth century, when Henri Maine and A. Dicey opposed unfree societies (ancien régime, feudalism, slavery) to free societies. In the former, the legal status of the actors conditioned their social, political, and economic actions, while in the latter the contract dominated. This view emerged in response not only to the abolition of slavery in the United States and serfdom in Russia, but also to the transformation of labour institutions in Europe and the United States. In particular, the emergence of collective bargaining and the welfare state was considered synonymous with the decline of freedom of contract and a resurgence of status, the latter being a distinctive feature of "old regimes". Ever since, several authors have developed this argument. ${ }^{8}$

However, during recent decades, this simplistic scheme has been increasing attacked; for ancien régime France, for example, it has been demonstrated that the division of society into "old orders" and corporative regulation had already weakened greatly, and to some extent had disappeared, by the early eighteenth century, ${ }^{9}$ while, on the other hand,

8. Henry Maine, Ancient Law: Its Connection with the Early History of Society, and its Relation to Modern Ideas (London, I86I); A.V. Dicey, Lectures on the Relation between Law and Public Opinion in England during the Nineteenth Century (London, 1905); R. Cleveland, "Status in Common Law", Harvard Law Review, 38 (1925), pp. 1074-1095; M. Rehbinder, "Status, Contract and the Welfare State", Stanford Law Review, 23 (197I), pp. 94I-955; G. Alpa, "La rinascita dello status", Materiali per una storia della cultura giuridica, 23 (2 December 1992), pp. 435-473; R.H. Graveson, "The Movement from Status to Contract”, The Modern Law Review, 4 (194I), pp. 26I-272; J. Hirschfeld, "Status", Journal of the Society of Comparative Legislation, 4 (1902), pp. I68-171; W. Friedmann, "Changing Functions of Contract in the Common Law", The University of Toronto Law Journal, 9 (195I), pp. I 5-4I; F. Tannenbaum, "Contract versus Status", Political Science Quarterly, 65 (1950), pp. I8I-192; O. Kahn-Freund, "A Note on Status and Contract in British Labour Law", Modern Law Review, 30 (1967), pp. 635-644; and P. Atiyah, The Rise and Fall of Freedom of Contract (Oxford, 1979).

9. M. Sonenscher, Work and Wages: Natural Law, Politics and the Eighteenth-Century French Trades (Cambridge, 1989); S. Chapman and S. Chassagne, European Textile Printers in the Eighteenth Century (London, I98I); N.Z. Davis, "A Trade Union in Sixteenth Century France", Economic History Review, 19 (1966), pp. 48-69; L.S. Kaplan, La fin des corporations (Paris, 2002); W. Sewell, Gens de métier et révolution. Le langage du travail de l'Ancien régime à 1848 (Paris, I983); S.R. Epstein, "Crafts, Guilds, Apprenticeship, and Technological Change in Preindustrial Europe", The Journal of Economic History, 58 (1998), pp. 684-713; and M. Berg, The Age of Manufactures, 1700-1820 (London, 1985). 
important status markers persisted under the liberal regime (in relation to the legal status of married women, children, and merchants, for example). This was true not only in France but also in Britain and Germany. ${ }^{10}$ According to this approach, the return of status in the twentieth century cannot be compared with old-regime status insofar as it appeals to rules and rights in order to reduce inequalities rather than to increase them. The world of labour, in particular the rights of workers under collective agreements in Europe and their fate on the one hand and the tough conditions endured by coolies, bonded people, and immigrants on the other, shows clearly enough the importance of this point for understanding past and present societies. ${ }^{\mathrm{I}}{ }^{\mathrm{P}}$ From this standpoint, the tension between legal status, contract, social conditions, and economic dynamics was a feature of the history of "coerced" labour as well as of "free" labour. Free and unfree labour on the one hand, status and contract on the other, are historically determined categories. We argue that those histories do not run in parallel but are strictly intersected. To prove this assertion, the papers in this volume have recourse to, first, a more complex relationship between written rules and legal procedures; secondly, an explicit analysis of the connections between legal and economic entitlements; and thirdly, a non-ethnocentric and global approach.

Rules first. The ways in which economic and social actors appropriate legal rules have been extensively studied in sociology, economics, history, and anthropology, and, of course, by legal scholars. The "effectiveness of law” reveals an anxiety widely shared among historians and expresses a particular approach to law. Laws are placed on the statute book but might then quickly become dead letters. Such laws are said to have little impact on the "real lives" of most people. Historians therefore want to know to what extent laws are enforced. This view misses the point: judicial statistics reveal not how rules affect the behaviour of ordinary people but merely the extent to which they are formally enforced. As a legal historian has stressed, there may for example be little enforcement and widespread disobedience, little enforcement and loss of compliance. ${ }^{\mathrm{I} 2}$ In studying "law in action" one has to keep in mind that the degree of litigation is not

\footnotetext{
Io. W. Steinmetz (ed.), Private Law and Social Inequality in the Industrial Age: Comparing Legal Cultures in Britain, France, Germany and the United States (Oxford, 2000).

I I. On Indian coolies, see for example J. Breman, Taming the Coolie Beast: Plantation Society and the Colonial Order in Southeast Asia (Delhi, I989); Emmer, Colonialism and Migration; S. Bhattacharya and J. Lucassen (eds), Workers in the Informal Sector: Studies in Labour History, I 800-2000 (Delhi, 2005); U. Patnaik and M. Dingwaney (eds), Chains of Servitude: Bondage and Slavery in India (Madras, 1985); and H. Tinker, A New System of Slavery: The Export of Indian Labour Overseas I830-1920 (London, 1974).

I2. Robert Steinfeld, Coercion, Contract, and Free Labor in the Nineteenth Century (Cambridge, 200I), p. 72.
} 
a measure of the impact of rules on "real life" but rather of the degree to which people have access to means to enforce their legal rights. ${ }^{13}$

From that point of view, social and economic inequalities are mutually linked to legal entitlements; a modification in legal entitlements strongly influences the economic and social equilibrium, and vice versa. Legal entitlement is measured not only by law texts, but above all by procedures, charges of proof, and access to law courts for example; that is, a whole set of procedural rules and institutions giving concrete opportunities for individuals to mobilize rules. Those opportunities are not available equally to everybody. Undoubtedly, servants and coolies, not to speak of serfs and slaves, enjoyed many fewer rights and juridical opportunities than their masters did. Still, those rights were not nonexistent, and that led to different social and economic equilibriums. ${ }^{14}$

We study this problem in detail, with fresh analyses of the interaction between legal status and economic conditions in tsarist Russia (in a comparative perspective) and pre-slavery-abolition Brazil. In particular, we show that the socioeconomic and legal conditions endured by serfs were much more elastic and open to negotiation than is usually asserted and that the so-called abolition of serfdom should therefore be seen within the context of a longer process of institutional change. Indeed, ex-serfs were subject to important legal constraints in post-emancipation Russia. "Serfs" were not serfs de la glèbe and ex-serfs were bound to landowners and, when working in manufactories, subject to strong legal constraints as well. Similarly, in Brazil, if bondage was extremely widespread after the abolition of slavery, ${ }^{\mathrm{IS}}$ conversely labour contracts were in use before that date for manumitted slaves trying to repay debts contracted to buy their freedom. The definition of "contract" was important in guiding the labour laws relating to Brazilian national and immigrant workers, as well as former slaves.

At least in the urban areas studied here, only former slaves entered into labour contracts, and those had their own logic and features. They included settlements and long-term engagements, with monetary debts being incurred to pay the costs of manumission. These outcomes have found important confirmation in other parts of the world, and above all in India. In fact, legally, Indian workers were servants under British law and,

I 3. Roscoe Pound was to first to develop this point. See Roscoe Pound, "Law in Books and Law in Action", American Law Review, 44 (1910), pp. I2-36. The so-called pragmatic school developed this approach further. See J. Willard Hurst, Law and the Conditions of Freedom in the Nineteenth-Century United States (Madison, WI, 1956); and William Novak, The People's Welfare: Law and Regulation in Nineteenth-Century America (Chapel Hill, NC, 1996).

I4. Laurent Benton, Law and Colonial Culture (Cambridge, 2002).

I s. For a bibliography see Cooper, Holt, and Scott, Beyond Slavery, and Scott, "Defining the Boundaries of Freedom". 
as such, they had far fewer rights than their masters (both British and Indians). ${ }^{16}$ In other words, rather than opposing the world of "freedom" and contract to the world of "unfreedom" and status, we measure the way rules, legal entitlements, and economic forces intervened in defining individual and social trajectories and hierarchies.

Underlying this conclusion is a perspective that is resolutely non-Eurocentric and global. We do not endeavour to find the "missing" freedom of contract in the "periphery", nor do we consider the "cultural" and economic domination of "the West" as a starting point. We stress instead the mutual connection between "peripheries" and "core" categories and practices. In particular, we do not judge the level of freedom and unfreedom in Brazil or Russia in terms of a general, let us say British, notion of free labour; instead we consider the historical interplay between the two.

The emergence of the ideology of freedom in Britain and the United States in the eighteenth and nineteenth centuries was quite complex and controversial, the economic and moral argument not always being compatible with it. ${ }^{17}$ This was equally true in France, where enlightened philosophers and "liberal" physiocrats expressed quite ambiguous attitudes towards the immediate abolition of serfdom and slavery, at least until the insurrection in Santo Domingo. And even after, Napoleon was quick to restore slavery, while Jean-Baptiste Say, Le Play, and even Bentham continued to express a desire to introduce Russian serf discipline in Europe. ${ }^{8}$ From that point of view, Russian and Brazilian perspectives on unfree labour were far from expressing the attitude of "backward" owners and elites. They reflected instead the ambiguities of European thought on this issue. In a similar and broader way, Clarence Smith has recently shown that the abolition of slavery in Islam reflected not just the impact of "Western influence" but that indigenous trends in that direction were already in motion. ${ }^{19}$

Such a bilateral circulation of ideas and practices contrasts with the argument according to which "the West" invented "freedom" and coercion as well. In various "Western countries" "freedom" acquired different

16. Prabhu Mohapatra, "Assam and the West Indies, I860-1920: Immobilizing Plantation Labor", in Douglas Hay and Paul Craven (eds), Master, Servants and Magistrates in Britain and the Empire, I562-I955 (Chapel Hill, NC, 2002), pp. 455-480; Ravi Ahuja, "The Origins of Colonial Labour Policy in Late Eighteenth-Century Madras", International Review of Social History, 44 (1999), pp. I 59-195; D. Chakrabarty, Rethinking World Class History: Bengal, I890-1940 (Princeton, NJ, 1989).

17. D. Brion Davis, The Problem of Slavery in the Age of Revolution, $1770-1823$ (New York, I999); R. Blackburn, The Overthrow of Colonial Slavery, I776-I848 (London, I988).

I 8. A. Stanziani, "Free Labor-Forced Labor: An Uncertain Boundary? The Circulation of Economic Ideas between Russia and Europe from the i8th to the Mid-I9th Century", Kritika: Explorations in Russian and Eurasian History, 9 (2008), pp. 27-52.

19. William Gervase Clarence-Smith, Islam and the Abolition of Slavery (Oxford, 2006). 
significances at different moments; conversely, freedom had different meanings outside Europe, as precolonial forms of bondage in India and Africa testify. ${ }^{20}$ This implies that the cultural and material circulation of models and men did not necessarily follow the centre versus periphery scheme. Indeed, the evolution of legal and economic notions and practices of masters and servants in Britain interacted with that of servants, coolies, and masters in India and the British Empire. Not only did the British regulation of labour mould into Indian practices; the evolution of British jurisprudence and legislation governing the relationship between master and servant were strongly influenced by Indian jurisprudence. Between the I 860 s and World War I, several projects aimed at codifying British law were all strongly influenced by Indian rules and jurisprudence. ${ }^{21}$ Bentham's and James Mill's ideals and approaches to the law, ${ }^{22}$ as well as the famous analysis of status and contract by Maine mentioned earlier, were strongly inspired by Indian regulation and jurisprudence.

This discovery opens new perspectives: Maine's analysis seems no longer to be linked exclusively to the emergence of the social state and welfare regulation in Europe; it is strongly connected to the "colonial question". This confirms that the history of "free" and "unfree" labour and that of forms of "contract" and "status" do not run in parallel but are connected. Stanziani's paper (pp. 359-389) confirms this mutual relationship between Russia and Europe and shows how deeply the notion of "serfdom" influenced notions and practices of labour in Europe. Again, forms of bonded labour in the "periphery" cannot be understood without recognizing how they interplayed with the evolution of notions and practices of labour in the "core".

However, the two papers here do not only revisit the circulation of ideas and the global political economy of labour; they wish also to revisit the historical dynamics. Our first point is that global economic dynamics from the seventeenth to the end of the nineteenth century (a period which saw "revolutions" in agriculture, trade, and consumption, protoindustrial

20. On India, see G. Prakash, Bonded Histories: Genealogies of Labour Servitude in Colonial India (Cambridge, 1990). On Africa, see P. Curtin, Economic Change in Precolonial Africa: Senegambia in the Era of the Slave Trade (Madison, WI, 1975); P. Lovejoy, Transformations in Slavery (Cambridge, 2000). Olivier Pétré-Grenouilleau, Les traites négrières (Paris, 2004); Catherine Coquery-Vidrovitch and Henri Moniot, L'Afrique noire de I 800 à nos jours (Paris, 1992); John Thonton, Africa and Africans in the Making of the Atlantic World (Cambridge, 1992); Claude Maillassoux, L'esclavage en Afrique précoloniale (Paris, I975); Paul Lovejoy, The Ideology of Slavery in Africa (Thousand Oaks, CA, 1981).

2 I. Elizabeth Kolsky, "Codification and the Rule of Colonial Difference: Criminal Procedure in British India", Law and History Review, 23 (2005), pp. 63 I-683.

22. Kartik Kalyan Raman, "Utilitarianism and the Criminal Law in Colonial India: A Study of the Practical Limits of Utilitarian Jurisprudence", Modern Asian Studies, 28 (1994), pp. 739-791. 
growth, and the first industrial revolution) were anchored to a notion and practices of labour as "service", in which the boundary between freedom and unfreedom was flexible and the master/employer acquired ownership of all the labour time of the worker/servant over the engagement period. Labour as service was at the root not only of serfdom and slavery, but also of the indentured, servants, and wage earners (labour being rented out as a service under a contract). ${ }^{23}$

This world changed slowly during the nineteenth century and collapsed only at the turn of the twentieth century. In fact, it was not only Russian serfs but also American slaves, English servants, and French loueurs d'oeuvre who saw no change in their legal status following a single reformatory act or statute; that change came only as the result of a longterm process of rule-making, judicial action, and economic dynamics. ${ }^{24}$ It was not until the middle, or in some cases towards the end, of the nineteenth century that labour rules were radically changed in all those countries and the "labour contract" as we know it today established. This coincided with a new notion of labour, the emergence of the welfare state and trade unions, and, last but not least, the second industrial revolution.

It is probably true that the notion and practices of "free labour" saw an unprecedented and wide success towards the end of the eighteenth and during the nineteenth century. However, this march was, at best, confined to western Europe and the United States; elsewhere twentieth-century practices were still strongly rooted in notions of labour as service and therefore to an uncertain boundary between freedom and unfreedom. Debt bondage and forms of servitude did not disappear in the second half of the nineteenth century, nor even in the century thereafter. On the contrary, they actually increased in Southeast Asia, Africa, and Latin America, as well as in the Soviet Union.

\footnotetext{
23. For France, see Alain Cottereau, "Droit et bon droit. Un droit des ouvriers instauré, puis évincé par le droit du travail (France, XIXe siècle)", Annales, 57:6 (2002), pp. I 52 I-I 557 . For the United States and Great Britain, see Steinfeld, Coercion, Contract, and Free Labor; and Simon Deakin and Frank Wilkinson, The Law of the Labour Market: Industrialization, Employment, and Legal Evolution (Oxford, 2005). For a comparison between Germany and Great Britain, see Richard Biernacki, The Fabrication of Labor: Germany and Britain, I640-I9I4 (Berkeley, CA, I995).

24. On the legal status of various forms of slavery and their comparison with indenture, serfdom, and other forms of coerced labour, see Engerman, Terms of Labor; Steinfeld, The Invention of Free Labor; and Bush, Servitude in Modern Times.
} 